\title{
Antitumor efficacy of EDTA co-treatment with cisplatin in tumor-bearing mice
}

\author{
Sabry Ali El-Naggar¹, Karim Samy El-Said ${ }^{\circledR *}$ \\ ${ }^{1}$ Department of Zoology, Faculty of Science, Tanta University, Egypt, ${ }^{2}$ Division of \\ Biochemistry, Department of Chemistry, Faculty of Science, Tanta University, Egypt
}

\begin{abstract}
Ethylenediamine tetraacetic acid (EDTA) is used in various medical applications. The aim of this study is to investigate the antitumor efficacy of EDTA alone or with cisplatin (Cis). Fifty male albino mice were used to assess the median lethal dose $\left(\mathrm{LD}_{50}\right)$ of EDTA via intraperitoneal (i.p) injection. To determine the antitumor activity, fifty female albino mice were divided into five groups as the following; Group 1 (Gp1) was negative control; (Gp2-5) inoculated i.p with $2 \times 10^{6}$ Ehrlich Ascites Carcinoma (EAC) cells/mouse. After one day, Gp3, Gp4 and Gp5 injected with Cis ( $2 \mathrm{mg} / \mathrm{kg})$, EDTA $(25 \mathrm{mg} / \mathrm{kg})$ and Cis $(2 \mathrm{mg} / \mathrm{kg}) /$ EDTA $(25 \mathrm{mg} / \mathrm{kg})$ for six days, respectively. At day 14, all groups were sacrificed to assess the tumor profile, liver enzymes (alanine transaminases and aspartate transaminases), kidney function (urea and creatinine) and electrolytes $\left(\mathrm{Na}^{+}, \mathrm{K}^{+}\right.$and $\left.\mathrm{Ca}^{2+}\right)$. The results showed that the i.p $\mathrm{LD}_{50}$ of EDTA was $250 \mathrm{mg} / \mathrm{kg}$. Treatment with EDTA alone did not show any antitumor activity and did not interfere with the antitumor efficacy of Cis. Biochemical findings revealed that EDTA had mild toxicity on liver and kidneys functions. In summary, EDTA had no antitumor effect and did not alter the Cis efficacy.
\end{abstract}

Keywords: Cisplatin. Ethylenediamine tetraacetic acid (EDTA)/Antitumor efficacy. Ehrlich Ascites Carcinoma.

\section{INTRODUCTION}

Ethylenediaminetetraacetic acid (EDTA) is known as a metal chelating agent. It is used in clinical setting to treat heavy metal intoxication such as lead, cadmium poisoning (Thomas et al., 2005; Myint et al., 2009). In addition, EDTA was used in combinations with other therapeutic agents to improve skin protection from sun radiation (Juzeniene et al., 2007). EDTA might prevent iron to form complex with doxorubicin, which could prevent damaging induced by reactive oxygen species (Hasinoff, 2006). It is commonly used also to treat cardiovascular diseases (Chappell, Janson, 1996). Furthermore, EDTA could be important as an adjuvant for increasing the intratumoral efficacy of cisplatin (Cis) treatment (Duvillard et al., 2004; Pajak, Orzechowski,

*Correspondence: K. S. El-Said, Division of Biochemistry, Department of Chemistry, Faculty of Science, Tanta University, Egypt. Mobile: +201002977062. E-mail: kareem.ali@science.tanta.edu.eg
2007). It may also inhibit the bleomycin nucleases activity, which in turn induces cancer cell apoptosis (Aouida et al., 2007). Recently, it has been reported that treatment of different cancer lines with EDTA in vitro showed antitumor activity (Feril et al., 2017).

In regard to the toxicity and the possible carcinogenicity of EDTA, several studies reported that the treatment with EDTA $(750 \mathrm{mg} / \mathrm{kg} /$ day $)$ was considered as the lowest dose that caused a toxic effect in animals but not carcinogenic agent (Kimmel, 1977).

Cisplatin (Cis) is a well-known as a potent chemotherapeutic agent to combat different types of cancers, including breast, prostate and bladder (Cepeda et al., 2007; El-Naggar, 2011). The mode of action of Cis is to cross-link with the DNA purine bases, which in turn interfere with DNA repair. DNA damage followed by activation of p53 resulting in cancer cells apoptosis (Damia et al., 2001). Combination therapies of Cis with other drugs have been highly considered to overcome drug-resistance, synergistic effects and reduce toxicities 
(Dasari, Tchounwou, 2014). For instance, it has been reported that ibuprofen administration with Cis accelerates the apoptosis (Endo et al., 2014). This study aimed to address the antitumor efficacy of EDTA on EAC-bearing mice and its impact on Cis treatment. The results indicated that EDTA treatment did not show any antitumor activity; however, treatment of mice with Cis and EDTA did not interfere with the mode of action of Cis as anticancer agent but exhibited mild toxicity on kidneys and liver tissues.

\section{MATERIAL AND METHODS}

\section{Chemicals}

Cisplatin (cis-diamminedichloroplatinum II) was purchased from the local pharmacy. It is manufactured by EIMC united pharmaceuticals, Egypt. Each vial contains $50 \mathrm{mg} / 50 \mathrm{~mL}$. At the time of treatment, Cis was diluted by $0.9 \%$ normal saline and adjusted to $2 \mathrm{mg} / \mathrm{kg}$ b.wt in $200 \mu \mathrm{L}$. EDTA was purchased from commercial company (Al-Gomhorea, Tanta, Egypt). EDTA was prepared as $25 \mathrm{mg} / \mathrm{kg}$ in $200 \mu \mathrm{L}$ of $0.9 \%$ sterilized saline.

\section{Mice}

Female Swiss albino mice weighting $20 \pm 2 \mathrm{~g}$ were obtained from National Research Center (NRC, Cairo, Egypt). Animals were housed (5/cage), in 12 $\mathrm{H} / 12 \mathrm{H}$ dark/light cycle under laboratory condition of temperature and humidity. Mice were kept for a week before starting the experiment for adaptation and then handled according to the ethical guidelines approved by the animal care and use committee, Faculty of Science, Tanta University (ACUC-SCI-TU), Egypt.

\section{Determination the median lethal dose $\left(\operatorname{LD}_{50}\right)$ of EDTA by intraperitoneal (i.p) injection}

To determine the lethal dose (LD50) that kills $50 \%$ of mice after i.p. injection of EDTA, fifty mice were divided into two main groups $(n=25)$ to repeat the experiment twice. Each group further divided into 5 subgroups of 5 mice per each. Then, these subgroups were injected i.p by different concentrations of EDTA $(0.1 \mathrm{~g} / \mathrm{kg}$ to $0.5 \mathrm{~g} / \mathrm{kg})$. Mice were noticed for $24 \mathrm{~h}$ to assess the acute toxicity of EDTA. LD50 value was calculated using the arithmetic method of Karber as modified by Aliu and Nwude (1982) according to the following equation, the theoretical LD50 = LDy - sum $(\mathrm{Dd} \times \mathrm{Md}) / \mathrm{N}$.

\section{Ehrlich Ascites Carcinoma (EAC) cells and tumor inoculation}

Ehrlich ascites carcinoma (EAC) bearing mice were purchased from the National Institute of Cancer (Cairo, Egypt). EAC cells were collected from the tumor bearing mice, and had diluted in sterile $0.9 \%$ saline. The viable and dead EAC cells were counted using trypan blue method and the number was adjusted at $2 \times 106$ cells/ mouse for inoculation. Total viable cells were calculated as following: Mean number of unstained cells $\times$ dilution $\times 104 / \mathrm{mL}$.

\section{Experimental design}

Fifty female Swiss albino mice were divided into five groups $(\mathrm{n}=10)$. Group $1(\mathrm{Gp} 1)$ served as a control and injected intraperitonially (i.p) with $200 \mu \mathrm{L}$ of $0.9 \%$ saline. Gp2 (EAC-bearing mice), mice inoculated i.p with $200 \mu \mathrm{L}$ of $2 \times 106$ cells/mouse on day 0 . Gp3, Gp4 and $\mathrm{Gp} 5$ were inoculated with the same number of EACcells as in Gp2. These groups were treated i.p either with Cis $(2 \mathrm{mg} / \mathrm{kg})$ or EDTA $(25 \mathrm{mg} / \mathrm{kg})$ or with Cis $(2 \mathrm{mg} / \mathrm{kg}) /$ EDTA $(25 \mathrm{mg} / \mathrm{kg})$. The treatment with saline, Cis, EDTA or EDTA/Cis started from day 1 until day 6. On day 14 , all groups were sacrificed to assess the tumor volume, count and live/dead cells.

\section{Determination the percentage of the total body weight changes}

All mice in the five groups under the study were weighted at day 0 , and then by day 14 . The percentage of the change in the total body weight (T.B.W) was assessed as follow: (T.B.W at day $14-$ T.B.W at day 0/T.B.W at day 0$) \times 100$.

\section{Biochemical and electrolytes assays}

Serum alanine transaminases (ALT), aspartate transaminases (AST), urea, creatinine, and total lipids were assayed by the colorimetric method using kit (Diamond-Diagnostics, Egypt). Additionally, electrolytes including calcium $(\mathrm{Ca} 2+)$, sodium $(\mathrm{Na}+)$ and potassium $(\mathrm{k}+)$ were assayed in serum by 
the colorimetric method using kit (DiamondDiagnostics, Egypt).

\section{Statistical analysis}

One-way analysis of variance (ANOVA) was used to assess the significant differences among treatment groups. Dunnet test was used to compare all groups against the control group to show the significant effect of treatment. The criterion for statistical significance was set at $\mathrm{p}<0.05$ or $\mathrm{p}<0.01$. All data are presented as mean $\pm \mathrm{SD}$.

\section{RESULTS}

\section{$\mathrm{LD}_{50}$ of EDTA after intraperitoneal (i.p) injection in mice}

According to the obtained results of the two separate experiments, the mortality rate of mice was calculated from each dose of EDTA. The results showed that the calculated LD50 of EDTA was $250 \mathrm{mg} / \mathrm{kg}$ after injection of mice i.p. as shown in Figure 1.

\section{Treatment with Cis decrease the total body weight of mice}

As shown in figure 2A, after 14-day of EACcells inoculation, the T.B.W of mice in all groups was determined and the percentages of the change in the weight were assessed. The results showed that groups of mice, which inoculated with EAC cells alone (Gp2) or inoculated with EAC cells and treated with EDTA (Gp3) showed an increase in the percentage of T.B.W. Groups of mice which inoculated with EAC-cells and treated with Cis $(\mathrm{Gp} 3)$ or mice inoculated with tumor cells and then treated with a combination of Cis/EDTA (Gp5) had no significant changes in their body weight when compared to Gp2.

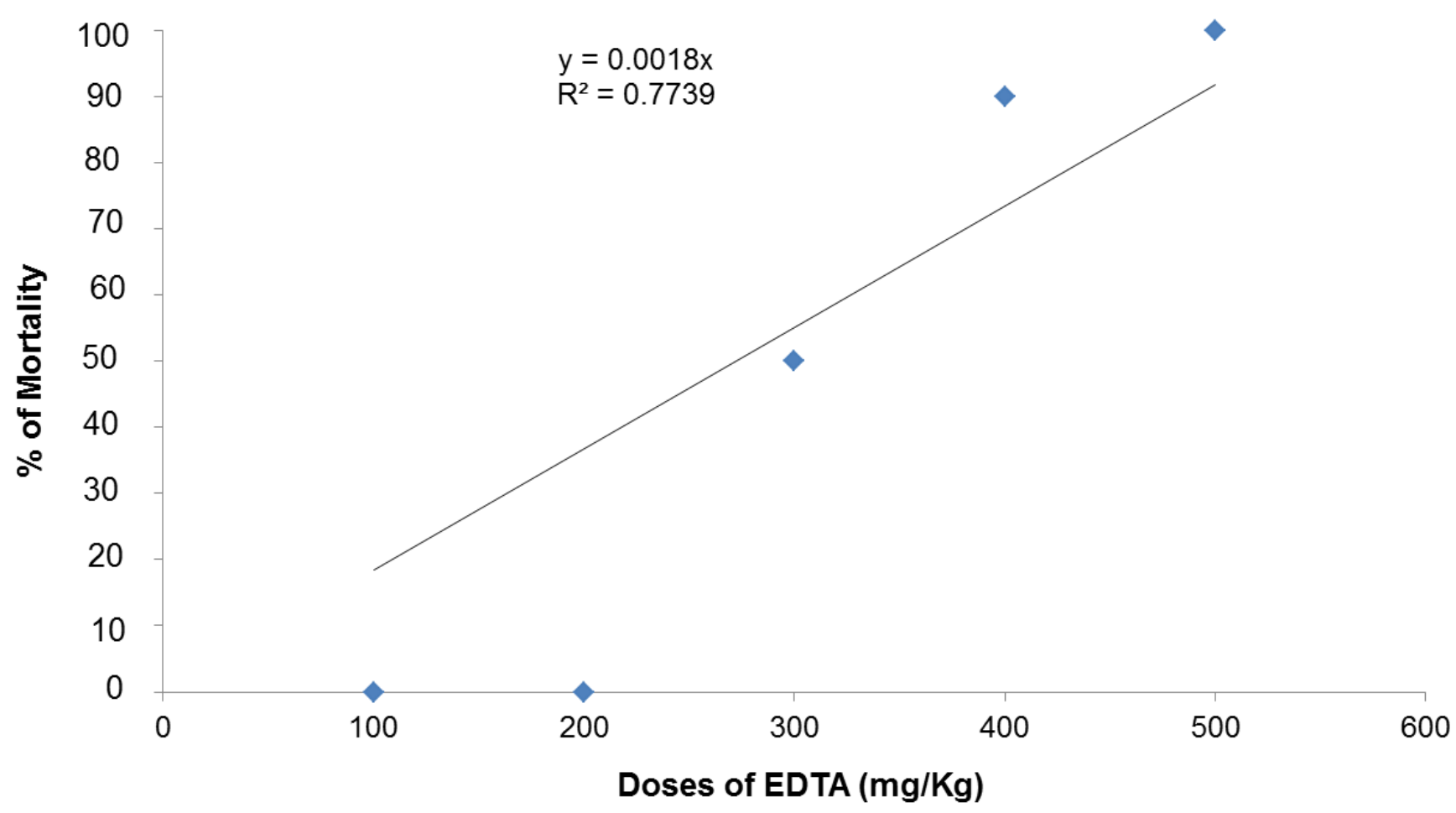

FIGURE 1- The median lethal dose (LD50) of EDTA injected intraperitoneal (i.p.) in albino mice. 

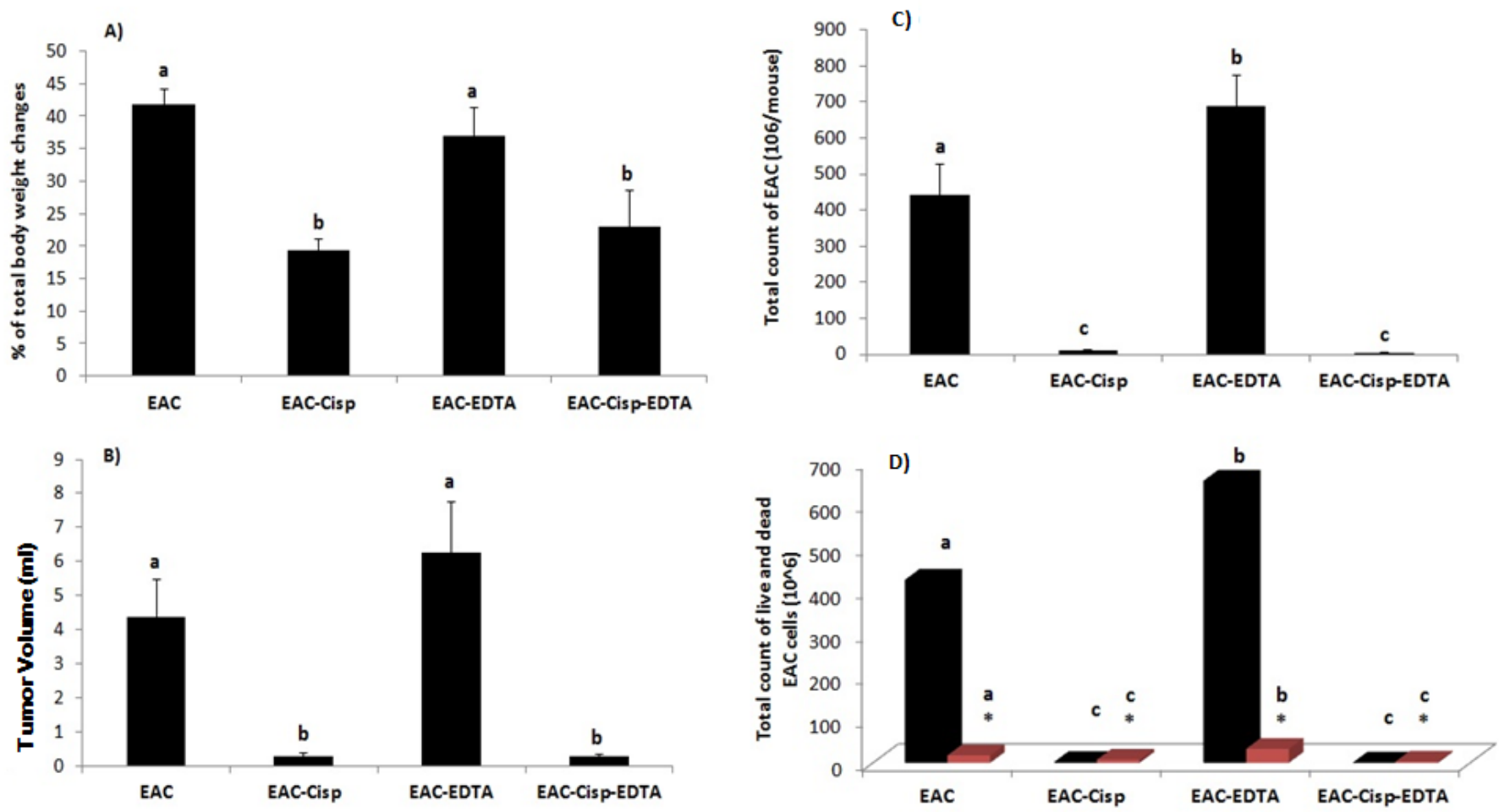

FIGURE 2- EDTA treatment did not show antitumor activity. A) The percentages of the change in the total body weigh in all groups, B) The tumor volumes. Co-treatment therapy with Cis/EDTA did not alter the efficacy of Cis antitumor. C) The total count of EAC cells, D) The viability of EAC cells represented by the live and dead tumor cells.

\section{Treatment with EDTA alone did not show antitumor effect in vivo}

Furthermore, to assess the antitumor effect of EDTA on EAC-bearing mice, the results showed that the treatment with EDTA alone for six consecutive days (Gp3) did not revealed any antitumor effect when compared to $\mathrm{Gp} 2$. As shown in figure $2 \mathrm{~B}$ treatment with Cis/EDTA treatment at the same time (Gp5) did not alter the efficacy of the Cis treatment when compared to Gp2. As shown in figure $2 \mathrm{C}, \mathrm{D}$ and figure 3 , the treatment with EDTA alone did not show any significant change in the tumor volume or the tumor counts when compared to the group of mice, which inoculated with EAC cells alone. Interestingly, the treatment with Cis/EDTA (Gp5) showed similar pattern in regard to the tumor cell count as in the group of mice which inoculated with EAC and treated with Cis alone (Gp3).

\section{Treatment with Cis/EDTA substantially increased ALT, AST and total lipids levels}

The results revealed that the levels of alanine transaminases (ALT) and aspartate transaminases (AST) were increased in groups Gp2 and Gp3. In addition, due to the combinatorial treatment of EDTA with Cis, a significant increase the serum ALT and AST levels when compared to Gp2 as showed in table I. Total lipids level in Cis-treated group or in group of mice which treated with EDTA alone were significantly increased when compared to Gp2. Combinatorial treatment of EDTA with Cis were significantly increased the level of total lipids in serum as compared with Gp2. (Table I). 


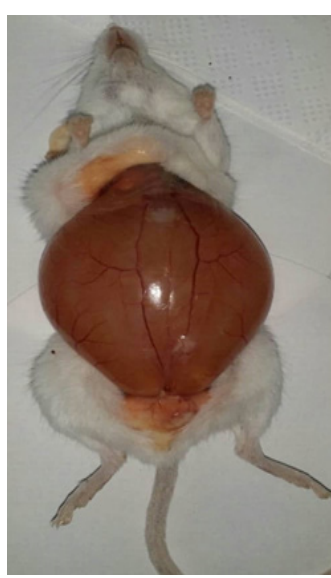

EAC-alone

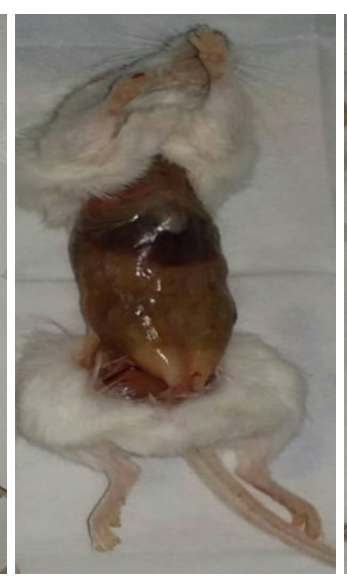

EAC/Cis.

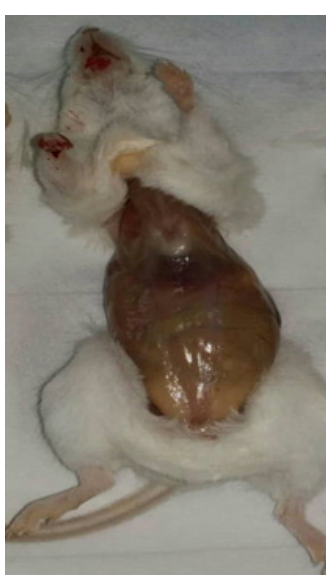

EAC/Cis/EDTA

FIGURE 3- Photomicrographs showed the tumor volumes of EAC-bearing mice (left side), EAC-bearing mice treated with Cis $(2 \mathrm{mg} / \mathrm{kg})$ (middle) and EAC-bearing mice treated with Cis $(2 \mathrm{mg} / \mathrm{kg}) / \mathrm{EDTA}(25 \mathrm{mg} / \mathrm{kg})$ (right side).

TABLE I - Serum alanine aminotransferase (ALT), aspartate aminotransferase (AST), urea, creatinine and total lipids in the different groups

\begin{tabular}{lccccc}
\hline & \multicolumn{5}{c}{ Biochemical parameters } \\
\cline { 2 - 6 } Groups* & $\begin{array}{c}\text { ALT } \\
(\mathbf{U} / \mathbf{L})\end{array}$ & $\begin{array}{c}\text { AST } \\
(\mathbf{U} / \mathbf{L})\end{array}$ & $\begin{array}{c}\text { Total lipids } \\
(\mathbf{m g} / \mathbf{d L})\end{array}$ & $\begin{array}{c}\text { Urea } \\
(\mathbf{m g} / \mathbf{d L})\end{array}$ & $\begin{array}{c}\text { Creatinine } \\
(\mathbf{m g} / \mathbf{d L})\end{array}$ \\
\hline Control & $19.5 \pm 1.5^{\mathrm{a}}$ & $84.8 \pm 2.9^{\mathrm{a}}$ & $145 \pm 3.5^{\mathrm{a}}$ & $18.19 \pm 0.59^{\mathrm{a}}$ & $0.35 \pm 0.03^{\mathrm{a}}$ \\
EAC alone & $23.9 \pm 1.0^{\mathrm{b}}$ & $119.3 \pm 2.5^{\mathrm{b}}$ & $295 \pm 2.5^{\mathrm{b}}$ & $25.72 \pm 0.75^{\mathrm{b}}$ & $0.58 \pm 0.014^{\mathrm{b}}$ \\
EAC/Cis & $33.4 \pm 2.21^{\mathrm{c}}$ & $154.0 \pm 1.7^{\mathrm{c}}$ & $437 \pm 2.9^{\mathrm{c}}$ & $44.01 \pm 0.84^{\mathrm{c}}$ & $0.87 \pm 0.04^{\mathrm{c}}$ \\
EAC/EDTA & $42.2 \pm 1.6^{\mathrm{d}}$ & $177.5 \pm 1.5^{\mathrm{d}}$ & $762 \pm 3.1^{\mathrm{d}}$ & $79.62 \pm 0.61^{\mathrm{d}}$ & $1.30 \pm 0.02^{\mathrm{d}}$ \\
EAC/Cis/EDTA & $36.9 \pm 2.5^{\mathrm{c}}$ & $162.1 \pm 2.0^{\mathrm{e}}$ & $413 \pm 3.9^{\mathrm{e}}$ & $59.62 \pm 0.94^{\mathrm{e}}$ & $\pm 0.06^{\mathrm{c}}$ \\
\hline
\end{tabular}

*Means that don't share a letter are significantly different

\section{Treatment with Cis/EDTA increased urea and creatinine levels}

Urea and creatinine levels were significantly increase in Cis-treated group and EDTA treated group when compared with Gp2. Co-treatment of EDTA with Cis showed a significant increases the level of urea and creatinine as compared with Gp2. (Table I).

\section{Treatment with Cis/EDTA altered some minerals level}

As shown in Table II, the levels of total calcium in EDTA-treated group were significantly decreased when compared with Gp2, Gp3 and Gp5. Sodium level in Cis/ EDTA treated group were increased when compared to Gp2, Gp3 and Gp4. The results also showed that potassium level did not reveal any significant changes in all-treated groups when compared with Gp2. 
TABLE II - Serum electrolytes, calcium $(\mathrm{Ca} 2+)$, sodium $(\mathrm{Na}+)$ and potassium $(\mathrm{k}+)$ concentrations in the different groups

\begin{tabular}{lccc}
\hline & \multicolumn{3}{c}{ Electrolyte levels } \\
\cline { 2 - 4 } Groups* & Calcium $(\mathbf{m m o l} / \mathbf{L})$ & Sodium $(\mathbf{m m o l} / \mathbf{L})$ & Potassium $(\mathbf{g} / \mathbf{d L})$ \\
\hline Control & $6.31 \pm 0.42^{\mathrm{a}}$ & $150.23 \pm 1.22^{\mathrm{a}}$ & $4.8 \pm 0.32^{\mathrm{a}, \mathrm{b}}$ \\
EAC alone & $7.13 \pm 0.91^{\mathrm{a}}$ & $148.26 \pm 2.53^{\mathrm{a}}$ & $4.1 \pm 0.58^{\mathrm{b}}$ \\
EAC/Cis & $6.51 \pm 1.45^{\mathrm{a}}$ & $138.96 \pm 3.07^{\mathrm{b}}$ & $5.2 \pm 0.23^{\mathrm{a}}$ \\
EAC/EDTA & $5.14 \pm 2.21^{\mathrm{a}}$ & $136.01 \pm 1.75^{\mathrm{b}}$ & $4.6 \pm 0.18^{\mathrm{b}}$ \\
EAC/Cis/EDTA & $6.86 \pm 1.52^{\mathrm{a}}$ & $158.13 \pm 3.07^{\mathrm{c}}$ & $5.8 \pm 0.71^{\mathrm{a}}$ \\
\hline
\end{tabular}

* Means that don't share a letter are significantly different

\section{DISCUSSION}

Cisplatin (Cis) is well known as a reference drug that act by binding DNA to form Cis-DNA adducts (Cepeda et al., 2007; Dasari, Tchounwou, 2014). On the other hand, EDTA is a metal chelating agent which able to combine with several metals so that it is used to remove heavy metals such as cadmium and lead from the body (Myint et al., 2009). EDTA is used as a potential therapeutic agent for vascular disease treatment (Ferrero, 2016). Furthermore, in clinical setting of ophthalmology EDTA has been utilized to treat band-shaped keratopathy (Kobayashi et al., 2015). In addition, Ca-EDTA chelation removes cadmium (Cd) intoxication (Gil et al., 2011). In this study, our aim was to address the direct antitumor effect of EDTA on EAC-tumor bearing mice and to address it's impact EDTA alone on the efficacy of the Cis treatment. Our data showed that the treatment with EDTA alone $(25 \mathrm{mg} / \mathrm{kg})$ for 6 consecutive days did not show any antitumor activity against EAC-bearing mice. This study was the first trial to explore the direct impact of EDTA on tumor bearing mice. A previous study showed that the intratumoral injection with EDTA increased the antitumor effect of Cis (Hasinoff, 2006). In addition, it has been reported that EDTA might prevent iron to form complex with doxorubicin, which could prevent reactive oxygen species damaging (Duvillard et al., 2004). A recent in vitro study showed that EDTA revealed antitumor activity against several tumor cell lines (Feril et al., 2017).
Furthermore, the study was extended to address the impact of the treatment with EDTA in combination with $\mathrm{Cis}$ against EAC-bearing mice. We thought that the treatment with EDTA and Cis at the same time could decrease Cis activity as anticancer agent. Our thought because that due to the possible chelation between EDTA and Cis. In contrast of our hypothesis, the results showed that there was no any significant impact of EDTA on the efficacy of Cis. One of our explanations for this unexpected result is that EDTA was able to remove calcium from the cell membranes, which in turn facilitate the entrance of Cis into the tumor cells. Our explanation in accordance with a previous finding, which reported that EDTA might increase the permeability of the intestinal epithelium by increasing the size of the membrane pores or by widening the spaces between the epithelial cells through the removal of calcium ions (LaDu, Mandel, Way, 1971). Due to the narrow window to determine the exact action of EDTA on the high dose of Cis. Further study is going to explore the direct effect of EDTA on the efficacy of the low dose of Cis after inoculation of EAC cells directly or after establishing EAC in mice model.

Treatment of EAC-bearing mice with EDTA for 6 days increased the percentage of the body weight more or less similar to those mice inoculated with EAC-cells alone; this finding indicated that the treatment with EDTA alone has no antitumor effect. Furthermore, treatment with EDTA alone showed also a similar 
pattern in regard to the tumor volume, counts of live and dead cells. These finding indicated that the treatment with EDTA alone has no antitumor effect.

The results revealed that inoculation with EAC for 14 days increased the levels of ALT, AST, urea and creatinine. Furthermore, the treatment with Cis alone or EDTA alone or their combination between EDTA and Cis increased the level of these parameters when compared to EAC-bearing mice alone. Acute exposure of EDTA may cause kidney injury, gastrointestinal upset, transient bone marrow depression; muscle cramps (Bingham, Cohrssen, Powell, 2001). Interestingly, the treatment of EAC-bearing mice with EDTA alone showed decrease in the level of calcium $(\mathrm{Ca}++)$. In agreement with our data, administration of EDTA decreased the coagulation factor activity resulted in a decrease in serum calcium levels causing profound hypocalcemia (Arla, Edward, 2008). Khalil et al. (2008) showed that treatment with EDTA altered antioxidant enzymes activity and biochemical parameters in the serum.

Consistent with our findings several studies reported that the treatment with EDTA $(750 \mathrm{mg} / \mathrm{kg} / \mathrm{day})$ was reported as the lowest dose that caused a toxic effect but not carcinogenic agent in animals (Kimmel, 1977). In conclusion, the data collectively showed that there is no anticancer activity of EDTA against EAC-bearing mice and did not alter the efficacy of Cis as anticancer agent.

\section{Conflict of interest}

All authors declare that they have no conflict of interests.

\section{REFERENCES}

Aliu YO, Nwude N. Veterinary pharmacology and toxicology experiments. Zaria: A.B.U. Press; 1982; p. 104-110.

Aouida M, Mekid H, Belhadj O, Mir L, Tounekti O. Mitochondria-independent morphological and biochemical apoptotic alterations promoted by the anti-tumor agent bleomycin in Saccharomyces cerevisiae. Biochem Cell Biol. 2007;85(1):49-55.

Arla J, Edward P. Pediatric fatality secondary to EDTA chelation. Clinic Toxicol. 2008;46(10):1083-1084.

Bingham E, Cohrssen B, Powell CH. Patty's Toxicology. v. 1-9. 5th ed. New York: John Wiley \& Sons; 2001; v.4, p. 769.
Cepeda V, Fuertes MA, Castilla J, Alonso C, Quevedo C, Pérez JM. Biochemical mechanisms of cisplatin cytotoxicity. Antianc Agents Med Chem. 2007;7(1):3-18.

Chappell LT, Janson M. EDTA chelation therapy in the treatment of vascular disease. J Cardiovasc Nurs. 1996;10(3):78-86.

Damia G, Filiberti L, Vikhanskaya F, Carrassa L, Taya Y, D'incalci M, Broggini M. Cisplatinum and taxol induce different patterns of p53 phosphorylation. Neoplasia. 2001;3(1):10-16.

Dasari S, Tchounwou PB. Cisplatin in cancer therapy: Molecular mechanisms of action. Europ $\mathrm{J}$ of Pharmacol 2014;740:364-378.

Duvillard C, Ponelle T, Chapusot C, Piard F, Romanet P, Chauffert B. EDTA enhances the antitumor efficacy of intratumoral cisplatin in s.c. grafted rat colon tumors. Anticanc Drugs. 2004;15(3):295-299.

El-Naggar SA. Lack of the beneficial effects of mirazid (Commiphora molmol) when administered with chemotherapeutic agents on ehrlich ascetic carcinoma bearing mice. Adv Biol Res. 2011;5(4):193-199.

Endo H, Yano M, Okumura Y, Kido H. Ibuprofen enhance the anticancer activity of cisplatin in lung cancer cells by inhibiting the heat shock protein 70. Cell Death Dis. 2014;5:e1027.

Feril JR, Ogawa K, Watanabe A, Ogawa R, Zheng-Guo C, Takashi K, Katsuro T. Anticancer potential of EDTA: a preliminary in vitro study. Mathews J Canc Sci. 2017;2(1):009.

Ferrero ME. Rationale for the successful management of EDTA chelation therapy in human burden by toxic metals. BioMed Res Int. 2016;2016:8274504.

Gil HW, Kang EJ, Lee KH, Yang JO, Lee EY, Hong SY. Effect of glutathione on the cadmium chelation of EDTA in a patient with cadmium intoxication. Human Exp Toxicol. 2011;30(1):79-83.

Hasinoff BB. Dexrazoxane use in the prevention of anthracycline extravasation injury. Future Oncol. 2006;2(1):15-20.

Juzeniene A, Juzenas P, Iani V, Moan J. Topical applications of iron chelators in photosensitization. Photochem Photobiol Sci. 2007;6(12):1268-1274.

Kimmel CA. Effect of route of administration on the toxicity and teratogenicity of EDTA in the rat. Toxicol Appl Pharmacol. 1977;40(2): 299-306. 
Khalil K, Ahmed A, Park H, Kim T, Park H, Abdel-Wahhab A. The inhibitory eVects of garlic and Panax ginseng extract standardized with ginsenoside $\mathrm{Rg} 3$ on the genotoxicity, biochemical, and histological changes induced by ethylenediaminetetraacetic acid in male rats. Arch Toxicol. 2008;82(3):183-195.

Kobayashi W, Yokokura S, Hariya T, Nakazawa T. Two percent ethylenediaminetetraacetic acid chelation treatment for band-shaped keratopathy, without blunt scratching after removal of the corneal epithelium. Clin Ophthalmol. 2015;9:217-233.

LaDu BN, Mandel HG, Way EL. Fundamentals of Drug Metabolism and Disposition. Baltimore: Williams and Wilkins; 1971; p. 35.
Myint KT, Uehara T, Aoshima K, Oda Y. Polar anionic metabolome analysis by nano-LC/MS with a metal chelating agent. Anal chem. 2009;81(18):7766-7772.

Pajak B, Orzechowski A. Ethylenediaminetetraacetic acid affects subcellular expression of clusterin protein in human colon adenocarcinoma COLO 205 cell line. Anticanc Drugs. 2007;18(1):55-63.

Thomas F, Séronie-Vivien S, Gladieff L, Dalenc F, Durrand $\mathrm{V}$, Malard L, et al. Cystatin $\mathrm{C}$ as a new covariate to predict renal elimination of drugs: application to carboplatin. Clin Pharmacokinet. 2005;44(12):1305-1316.

Received for publication on $30^{\text {th }}$ September 2018 Accepted for publication on $20^{\text {th }}$ February 2019 